\title{
Oruç Bey’in Aktardığı Efsaneler ve Bunların Türk Efsaneleri İçindeki Yeri
}

\author{
ELIF DÜLGER*
}

\begin{abstract}
ÖZ
Yüzyıllardır varlığını koruyan sözlü kültür ürünlerinden olan efsanelerin sınıflandırılmasında bir ana başlığın "tarihî efsaneler" adını taşıması, tarih kitaplarının efsaneler ile ilişkisini gösteren en önemli delildir. Özellikle savaş ve fetihlerin anlatıldığ kısımlarda bunlara ilişkin efsanelerin, bazı tarihî kahramanların anlatıldığı kısımlarda ise onların etrafında oluşmuş efsanelerin karşımıza çıkması hemen her tarihî kaynakta görülen bir husustur. Bu çalı̧̧manın amacı, 15. yüzyıl Osmanlı müverrihlerinden Oruç Bey'in Tevârib-i Âl-i Osman adlı eserinde yer verdiği efsanelerin tespit edilmesidir. Oruç Bey sadece bir tarih kitabı yazmakla yetinmemiş, atasözleri, deyimler, beddualar, efsaneler, halk inançları, gelenekler, âdetler, yer adlarının veriliş hikâyeleri gibi pek çok kültürel bilgiyi de eserine kaydetmiştir. Söz konusu eser, Osmanlı İmparatorluğu'nun ilk iki yüzyıllık tarihi kadar, o devrin Türk kültürünü araştırmak isteyenler için de önemli bir kaynaktır.
\end{abstract}

Anahtar sözcükler: Türk efsaneleri, tarihî efsane, dinî efsane, Oruç Bey, Tevârib-i Âl-i Osman

\section{Giriş}

Tevârihb-i Âl-i Osman adlı bir eser kaleme alan 15. yüzy1l Osmanlı müverrihlerinden Oruç Bey hakkında elimizde yeterli bilgi bulunmamaktadır. Zira Osmanlı biyografi kitaplarında ve tezkirelerinde onunla ilgili bilgi kaydedilmemiştir. Eserin Cambridge ve Manisa nüshalarında, kendisini "Oruç b. Âdil el-kazzâz kâtibü'l-Edrenevî” olarak tanıtmakta ve bu bilgiye göre kâtip adıyla anıldığı, Âdil adlı bir "kazzaz" ın yani “ipekçi”nin oğlu ve Edirneli olduğu anlaşılmaktadır. Doğum ve ölüm tarihi kesin olarak bilinmemekle birlikte

\footnotetext{
* Arş. Gör., Necmettin Erbakan Üniversitesi, Ortaöğretim Sosyal Alanlar Eğitimi Bölümü/KONYA
} e-posta: elif_dulger@hotmail.com 
15. yüzyılın ikinci çeyreğinde doğduğu, eserinin yeni nüshasını yazdığ 1502 yılında ya da kısa zaman sonra öldüğü tahmin edilmektedir (2008: XXIII).

Klasik dönem Osmanlı tarih yazıcılarından olan Oruç Bey'in Tevârihb-i $\hat{A l-i}$ Osman adlı eseri, devletin kuruluşundan 908 (1503) yılına kadar gelen bir Osmanlı tarihidir. Eser, Osmanoğullarının şeceresi ile başlar ve onların Horasan'dan Anadolu'ya göçleri ve yerleşimleri hakkındaki bilgilerle devam eder. Sonra sirasıyla Ertuğrul Gazi, Osman Gazi, Orhan Gazi, I.Murad, I.Bayezid, I.Mehmet, II.Murad, II.Mehmet ve II.Bayezid devirleri anlat1lır. Yazar, II.Mehmet devrini anlattıktan sonra Kostantiniyye ve Ayasofya efsaneleri ile Hz. Muhammed, dört halife, Emeviler ve Abbasiler hakkında bilgi veren İslâm tarihi bölümleri eklemiş ve sonra kronolojik sıraya uygun olarak II.Bayezid devrine geçmiştir.

Eserin dili, Eski Türkiye Türkçesinin son devresine (13.-15. yüzyıllar) girer. Kullanılan sade Türkçe ile eser, Türk nesir dilinin gelişmesindeki önemli bir merhaleyi yansıtmaktadır (2008: XXXII). "Oruç Bey ve çağdaşı Âşık Paşazâde Türkiye Türkçesinin nesir dilinin gelişmesinde önemli kilometre taşlarıdır" (2008: XXXII). İncelendiği zaman görülecektir ki eser, Türk kültür tarihi açısından büyük öneme sahiptir. Oruç Bey sadece bir tarih kitabı yazmakla yetinmemiş, yer adlarının veriliş hikâyeleri ${ }^{1}$, düğün, hediye, çeyiz, yemek, eğlence ve şenlik, giyim kuşam, ev eşyaları, inanışlar gibi pek çok kültürel bilgiyi de eserine kaydetmiştir ${ }^{2}$. Metin, Osmanl İmparatorluğu'nun ilk iki yüzyıllık siyasi tarihini araştırmak isteyenler kadar, o devrin Türk kültürünü araştırmak isteyenler için de son derece önemli bir kaynaktır.

\section{Tevârib-i Âl-i Osman'da Efsaneler}

Şahıs, yer veya olaylar hakkında anlatılan, gerçek olmamalarına rağmen inandırıcılık vasfi bulunan kısa halk anlatıları şeklinde tanımlayabileceğimiz efsaneler, Türk kültürünün ve edebiyatının en önemli sözlü ürünlerindendir. Başlıca niteliği inanışları konu alması olan ve insanlarca gerçekten yaşandığı kabul edilen bu sözlü gelenek ürünleri, ilk insandan bugüne uzanan süreçte ayrı coğrafya ve kavimlerde doğup gelişmiş ve zamanla insanların inanış, âdet ve çeşitli törenlerinin oluşumunda rol oynamıştır (Elçin 2001: 314).

Pertev Naili Boratav, École Pratique des Hautes Études'de görev yaptığ 19631964 ders yilında, daha önce Budapeşte'de International Society for Folk Narrative Research tarafından kabul edilen efsane sınıflandırmasının Türk

1 Bu konuda bir çalışma için bk. Elif Dülger (2012), “Oruç Bey'in Tevârih-i Âl-i Osmân Adlı Eserine Göre Türklerde Yer Adı Verme Geleneği”, Turkish Studies 7/3, s. 1067-1074.

2 Geniş bilgi için bk. Necdet Öztürk (2011), Saray Penceresinden 14-15. Yüzyzl Osmanl Sosyal Hayatı, İstanbul: Yitik Hazine Yayınları. 
efsanelerine uygun olmadığını belirterek kendisi bir sınıflandırma yapmıştır (Sakaoğlu 2009: 31). Boratav'ın tasnifi şu şekilde karşımıza çıkmaktadır:

I. Yaratılış Efsaneleri - Oluşum ve Dönüşüm Efsaneleri - Evrenin Sonunu Anlatan Efsaneler

II. Tarihî Efsaneler

III. Olağanüstü Şahıslar ve Varlıklar Üzerine Efsaneler

IV. Dinî Efsaneler (2000: 100-105)

Oruç Bey'in eserindeki efsaneler, yukarıdaki sınıflandırmaya bağlı kalınarak, tarihî ve dinî efsaneler olarak iki grupta incelenmiştir. Eserde yer adı verme geleneği içerisinde yer alan efsaneler ile Kostantiniyye ve Ayasofya efsaneleri daha önce başka çalışmalarda ele alındığı için burada bu efsaneler değerlendirmeye alınmayacaktır. ${ }^{3}$

\section{Tarihî Efsaneler}

Boratav, tarihî efsanelerin yazılı edebiyatta "menkıbe" adıyla anılan anlatıların tümünü kapsadığını belirtmekte ve bunları on iki alt başlıkta tasnif etmektedir (2000: 101). Burada "tariĥ̂" kelimesinden kastedilen ise şudur: "[B]ütün bir ülke veya ulusun geçmişinde önemi olan adı, çağı belli, ünleri yazılı belgelere geçmiş olaylar ve kişiler değil, bir toplumun kendi geleneğinde benimsediği, kendi geçmişine değin bildiği, çocukluk çağları, adları bile bilinmeyen kişiler ve onların maceraları" (2000: 103). Oruç Bey'in eserinde yer alan tarihî efsaneler; felaketlerle ilgili olanlar ve fetih efsaneleri olarak ikiye ayrilabilir.

\subsection{Felaketler ile İlgili Efsaneler}

Efsanelerde karşılaştığımız önemli bir motif olan beddua, söylendiği andaki duyguları ifade etmesi, ruh hâlini yansıtması bakımından önem taşır (Kaya 2001: 23). Efsanelerde beddualar, kimi zaman zulme uğrayan halk, kimi zaman kapıdan eli boş çevrilen bir derviş, kimi zaman ise kendisine karşı gelen halkı için bir peygamber, bir padişah tarafindan edilir. İslam inancına göre, mazlumun zalime karşı ettiği beddua Allah tarafından kabul edilir ve zalimler felakete uğrarlar. İmam Buhari'nin aktardığı hadislerde de bunu açıkça görmekteyiz: "Mazlûmun bedduâsından sakının! Zirâ mazlûm ile Allah arasında (duânın kabulüne) hiçbir perde yoktur” (Zebîdî 1986: 303).

Hemen her kültürde yer aldığını gördüğümüz Nuh Tufanı, Kur'an'da anlatılan kıssalar arasında, üzerinde en çok durulanlardan biridir. Hz. Nuh'un gönderildiği kavmin uyarılara ve öğütlere kulak asmaması, gösterdikleri tepkiler

3 Kostantiniyye ve Ayasofya efsaneleri için bk. Stefanos Yerasimos (2012), Türk Metinlerinde Kostantiniyye ve Ayasofya Efsaneleri, İstanbul: İletişim Yayınları. 
ve olayın meydana gelişi birçok ayette detaylarıyla anlatılır. Hz. Nuh, Allah'ın ayetlerinden uzaklaşarak O'na ortak koşan kavmini, sadece Allah'a kulluk etmeleri ve sapkınlıklarından vazgeçmeleri konusunda uyarmak amacıyla gönderilmiştir. Kavmine Allah'ın dinine uymaları konusunda defalarca öğüt verdiği ve onları Allah'ın gazabına karşı birçok kez uyardığı hâlde, kavmi Hz. Nuh'u yalanladı ve şirk koşmaya devam etmiştir. Israrla hak dine davet ettiği ancak bir türlü imana yanaştıramadığı kavmi için Hz. Nuh şöyle beddua etmiştir: "Nûh, şöyle dedi: 'Ey Rabbim! Kâfirlerden hiç kimseyi yeryüzünde bırakma! Çünkü sen onları bırakırsan, kullarını saptırırlar; sadece ahlâksız ve nankör (insanlar) doğururlar (yetiştirirler)'" (Kur'ân-ı Kerîm Açılamalı Meâli 2002: 575). Hz. Nuh'un bu bedduasindan sonra kendisine Allah tarafindan, kavminin suda boğulacağı haberi verilir:

Bunun üzerine Nûh'a, 'Bizim gözetimimiz altında ve vahyimize göre o gemiyi yap' diye vahyettik. Bizim emrimiz gelip de tandır kaynamaya başlayınca, (sular coşup taştı̆̆ında Nûh'a) dedik ki: Her cins canlidan (erkekli dişili) birer çift, bir de kendileri aleyhinde daha önce hüküm verilmiş olanlardan başka aileni gemiye al ve zulmeden kimseler hakkında bana hiç yalvarma! Şüphesiz onlar suda boğulacaklardır.

(Kur'ân-ı Kerîm Açıklamalı Meâli 2002: 333)

Nuh Tufanı'ndan anlaşıldığı üzere, bir peygamberin bedduası kavmini yok oluşa götürmektedir. Oruç Bey, Sultan Bayezid'in bedduasından sonra can veren Mesih Paşa'nın ölümünü aktardıktan sonra, padişahların bedduasından sakınmak gerektiğini, zira onların Allah'ın emir ve yasaklarıyla, yani şeriatla hükmettiklerini belirtmektedir. Bu ifade, Kur'an'da belirtilen peygamber beddualarına işaret etmekte ve Osmanlı padişahlarına kutsiyet yüklemektedir. Oruç Bey'in aktardığı bir rivayete göre, Sultan Bayezid Han, başına birkaç kez vurup "Hak tebâreke ve taâlâ tarafindan nâgâh bir kazâya uğrayasın” demek suretiyle Mesih Paşa'ya beddua etmiş ve Paşa yanındakilerle birlikte can vermiştir. Hatta burada Oruç Bey, "kurunun yanında yaş da yanar" atasözünü beyit hâlinde vermiştir.

Bir başka rivayette, Mesih Paşa'nın ölümüne sebep olan olay aktarılmıştır. Buna göre Mesih Paşa ile Galata kadısı ve emini, gemilere lâzım olduğu için Galata karşısındaki bir burgazda var olan güherçileyi çıkarırlar. Bu esnada ansızın gökyüzünde bir bulut belirir, yağmur yağar, şimşekler çakar ve burgaza yıldırım düşer. Bunun üzerine burgazın taşları havada uçmaya başlar. Bu sırada taşlardan bir tanesi Mesih Paşa’nın uyluğuna gelir, ayağı kırılır ve orada can verir. Bu olayda Mesih Paşa ile Galata kadısı haricinde hiç kimseye bir şey olmaz. Bu rivayetten sonra Oruç Bey, Sultan Bayezid'in beddua ettiği rivayeti verir ve Mesih Paşa’nın ölümünü bu bedduaya bağlar:

Ve girü bir hâdise dahı olup şehr-i Kostantiniyye'de vâkı‘ oldı, Cemâziyelevvel'üy altıncı gün Çehârşenbih gün, Teşrîn-i âhir'üy yigir- 
mi ikinci güninde Galata karşusında bir burgozda güherçile varımış. Ol hînde gemiler yaragı içün güherçile hâcet olup lâzım olmış. Vezîr Mesîh Paşa dirler ve Galata kadısı ve emîni bile varurlar kim, a'vân-1 ensâr1la güherçile çıkaralar. Nâgâh havâda gök yüzinde bir bulut peydâ olup, ol gice Çehârşenbih gicesi idi, gayet yagmur yagup, şimşekler oynayup, yıldırımlar şakıyup, bir sâ‘ika kopup yıldırım inüp, güherçile olan burgoza inüp, urup, ol burgozun taşları rîze rîze olup, her tarafa atılup çün hâl böyle oldı. Bu tarafdan paşalara haber, paşalar ve agalar ve yeniçeriler cem‘ olup Galata'ya geçüp, ya'nî odı söyündürüp halâs idelerdi. Ol yerde bu aralıkda nâgâh kazâ-yı âsmânî irişüp bir taş gelüp vezîr Mesîh Paşa'nun bir uylugına taş dokınup, bir ayagı sınup, ol zahmetden Mesîh Paşa helâk olup ve Galata kadısı bile helâk oldı. Ol ikisiden gayrı kimesne helâk olmadı dirler. Ammâ ecel irdi Mesih Paşa'ya.

Ve illâ bir râvî rivâyet idüp eydür kim: Mesîh Paşa ölmezden öndin Mesîh Paşa'yla Sultân Bâyezîd Han arasında bir kaziyye vâkı' olmış imiş. Midinlü kal'asından feryâdcılar gelmiş imiş. Fireng gemileri düşmen üzerimüze geldi diyü. İki üç defa ol feryâdcıları pâdişâha dimiş imiş. Soyra pâdişâh ol kaziyyeye muttali` olup hışm idüp, pâdişâhun elinde bir yayı olup ol yayıla Mesîh Paşa'yı birkaç kerre başına urup bed-duâ idüp, Hak tebâreke ve ta âlâ tarafindan nâgâh bir kazâya uğrayasın diyüp bed-du'â itmiş. Ol idi kim, Mesîh Paşa ve vartaya ugradı helâk oldı, yanındagılar dahı anuy kazâsına uğradılar.

Beyt

Meseldür kim dinilür halk katında

Ki yaş dahı yanar kurı katında

İmdi iy azîzler! Pâdişâhlarun bed-duâsından gâfil olmamak gerekdür sakınmak gerekdür, ale'l-husûs kim, İslâm pâdişâhı ola şerî́at icrâ idüp adl ü dâd issi ola. (2008: 214-215)

Teşekkül ettikleri bölgenin karakterini yansıtan efsaneler, aynı ülke içinde değişik şekillerle anlatıldıkları gibi, başka ülkelerde de anlatılabilirler (Seyidoğlu 1986: 359). Bilge Seyidoğlu'nun Erzurum ve Norveç halkı arasında anlatılan ve gezgin efsaneler olarak adlandırılan efsaneler üzerinde yaptığı çalışmaya bakıldığında, Oruç Bey’in aktardığı bu efsanenin de gezgin bir efsane olduğu görülecektir. Nitekim Seyidoğlu'nun aktardığı bir Norveç efsanesinde, kendisini ziyaret etmesini isteyen kadının uyarılarını dikkate alan adamın hayatında her şeyin yolunda gittiği, kulak asmamaya başladığı zaman ise peşini kötü şansın asla bırakmadığı anlatılmaktadır (aktaran Seyidoğlu 1986: 360).

Oruç Bey bu efsaneyi, depremden sağ kurtulan adamdan dinleyip eserine almıştır. Bu efsanedeki derviş, belirtilmemiş olmakla birlikte, Hz. Hızır olarak düşünülebilir. Nitekim, Hz. Hızır'ın çeşitli kılıklara girip insanlara felaketleri haber vermek suretiyle onları felaketten koruma noktasında yardim etme özelliği olduğu bilinmektedir. 
Ve girü mübârek Şa'bânü'l-mu'azzam ayınuy on yedisinde Cum‘a güninde gayet ile yir deprendi. Şöyle kim, Siroz tarafinda Filibecük dirler, anuy karşusında iki pâre köy aşaga geçdi dirler. Bir râvî rivâyet itdi kim, kendü başına gelmişdür. Didi kim: 'Ben ol gicede taşrada bulundum. O1 gice benüm evüm ve on sekiz baş cemấatüm ve bin dâne koyunum ve su sıgrrlarum ve öküzlerüm ve ineklerüm cümle aşaga geçdi belürsiz oldı' didi. Evet ol kişi rivâyet itdi kim, ol gün ahşam vakt bir dervîş̧ gelüp, ol köylerde bu kaziyyeyi işâret itmişdi dir. Masharalıga aldılar gülüşdiler didi. Anuy içün ol gice ben ve hatunum ile köyden taşra gitmişdük. Hemân bir ben bir hatunum kurtuldı didi. Ve iki yüzden ziyâde dahı âdem helâk oldı dirler, bile yere geçdi dirler. (2008: 217-218)

\subsection{Fetih Efsaneleri}

Fetih efsaneleri ile ilgili olarak anlatılan "didon hilesi" adlı motif, fethedilecek bölgeye gelen bir hükümdarın, şehrin hükümdarından bir sığır derisi büyüklüğünde yer istemesi, sonra da bu derinin sırım haline getirilmesi sonucu çok daha büyük bir toprak elde edilmesi hilesidir. Hâlen Afrika, Asya ve Avrupa'da anlatılan bazı efsanelerde bu motif karşımıza çıkmaktadır (Karadavut 2011: 647). Fenikelilerin Kartaca'yı, Hasan Sabbah'ın Alamut'u, Fatih'in İstanbul'u, Rusyalı Yermak'ın Güney Sibirya'yı ele geçirmesini konu alan efsanelerde bu hile anlatılmaktadır (Boratav 2000: 99). Evrensel bir nitelik kazanmış olan bu motif, Yunan mitolojisi kaynaklıdır ve Kartaca şehrinin kurulması olayında karşımıza çıkar. Buna göre, Fenike şehri olan Tyros'un kralı Pygmalion, amcası ve aynı zamanda da kız kardeşi Dido'nun kocası olan Sicharbas'ı öldürtünce Dido, şehrin seçkin aileleriyle birlikte ülkeyi terk ederek Afrika'nın Libya k1yılarına gider. Kurmak istediği şehrin yerlileri onları iyi karşılar ve sığır derisi büyüklüğünde bir toprak beğenip oraya yerleşebileceklerini söylerler. Dido, bu deriyi ince şeritler hâlinde kesip şehrin etrafinı çevreleyerek bir kent kurar. Bu kent sonradan Kartaca adiyla anılacaktır (Erhat 2003: 88-89).

$\mathrm{Bu}$ efsane her ne kadar Kostantiniyye ve Ayasofya efsaneleri içinde yer alsa da, motifin eskiliği ve önemi nedeniyle çalışmaya dâhil edilmiştir. Didon hilesi ile ilgili olarak Oruç Bey bir efsane aktarmaktadır. Buna göre, Harun Reşid, halifeliği sırasında Kostantin'e gelir ve hükümdar İlyan'dan bir sığır derisi büyüklügünde yer ister. İlyan bunu kabul eder ve Seyyid-i Battal Gazi bu sığır derisini dilimleyerek şehrin bir tarafını çevreler. Buradan kâfirleri çıkarıp Müslümanları yerleştirirler:

Ol zamân Harkıl tekür vefât itmişdi. Bir oglı kalmışdı, adına İlyan dirlerdi. Ol beg old. Ol zamânda halîfe Harunü'r-Reşî̀ idi. Ol dahı varup yüz elli bin erile âdemile varup Kostantin'i hisâr idüp girü zebûn itdiler. Girü sulh olunup şehri sulhıla virdiler. Girü içinde mescid yapdılar. Sultân Ca'fer-i Seyyidî Gâzî kâfirlerle şol şartıla itdi kim, bir sı̆ğır 
göni mikdârı şehrüy içinde yir dutalar. Anlar dahı râzı olup Seyyid-i Battâl Gâzî vardı, bir sığır gönini kiriş gibi dildi. Uzadup şehrüy bir tarafını dutdı. Kâfirlerini çıkarup bị müslimân evini yapdılar içine koydılar. Ve on mescid yapdılar. Ve on yıllık harâcını alup girü döndiler. Her yılda elli bin fülori harâca kesdiler gelüp gitdiler. (2008: 110)

Bu efsaneyi Evliya Çelebi de Seyahatname'de aktarmaktadır. Oruç Bey, şehrin hangi kısmının bu sayede alındığından bahsetmez. Ancak, Evliya Çelebi'ye göre burası halife Hz. Ömer devrinde Kocamustafa Paşa semtinde kalan bir mahalledir:

\begin{tabular}{|c|}
\hline $\begin{array}{l}\text { yüz elli bin asker ile İslâmbolıu muhâsara edüp âhir } \\
\text { müşkildir deyü sulha terğîb edüp İslâmbol içre kıraldan } \\
\text { yer isteyüp İlya[na] Kıral ricâsın kabûl edüp Hârûnu’r-I } \\
\text {-isini incecik dildirüp mukaddemâ Ömer ibn Abdül'azîz } \\
\text { hustafâpaşa semtinde kalan bir mahalle Sahâbe-i kirâmır } \\
\text { ina \{mezkûr sığır derisi dilimi cirminde\} metânet üzre b } \\
\text { şâ edüp içine dahi asker ve me'kûlât [ü] meşrûbâtların kc }\end{array}$ \\
\hline
\end{tabular}

Didon hilesi motifi ile ilgili olarak Evliya Çelebi'nin aktardığı bir başka efsane, İstanbul'un fethi ile ilgilidir. Buna göre, Kostantin'e dost gibi görünen ve ona hediyeler yollayan Fatih Sultan Mehmet, ondan Rumelihisarı'nda bir av köşkü ve saray çiftliği yapmak için bir sığır derisi büyüklüğünde yer ister. Gizli bir Müslüman olan rahip Aristo'nun görüşüyle bu deriyi gergiye gerdirip, ince bıçağıyla dilim dilim edip, o büyüklükte yalçın kayalar üzerinde hisarı inşa eder. Kostantin bunu duyunca barışa aykırı bir kale yaptığı düşüncesiyle Fatih Sultan Mehmet'e elçi gönderir. Fatih ise, "İşte izniniz ile yine bu sığır derisi büyüklüğünde yaptık. Ĕger daha fazla yaptıksa izninize muhalefet etmiş oluruz. Fazlasını yıkalım” şeklinde yumuşak ve akıllıca cevap verir (2006: 224-225).

\section{Dinî Efsaneler}

Anadolu sahası efsaneleri incelendiği zaman dinî efsanelerin ilk sırayı aldığı görülmektedir. Bunların içinde en fazla olanı da velilerin kerametleri üzerine anlatılan evliya menkıbeleridir. Velilerin savaş esnasında askerlere yardım edip savaşması Anadolu'nun pek çok yerinde hâlen anlatılmaktadır (Karadavut 1992: 111). Bunlar arasında adı belirtilmeksizin erenler ve evliyalar şeklinde karşımıza çıkan dinî efsaneler olduğu gibi, adı belirtilen efsaneler 
de vardır. Bunlar genellikle belli bir yerde medfun veliler için o yerin halkı tarafından anlatılır. Mersin'deki Kırtıl Dede (Alptekin 1980: 6), Ağrı'daki Ahmed-i Hani (Alpaslan 1991: 46), Yozgat'taki Şemunel Gazi (Karadavut 1992: 113) bunlara örnek olarak verilebilir. Ayrıca Hz. Hızır da, iki ateş arasinda kalan, mermisi tükenen, esir ya da esir olmak üzere olan askerlere yardım etmesiyle bu menkıbeler arasında yer almıştır (Ocak 2007: 116).

Velilerin savaşlarda yardım etmeleri ile ilgili olarak anlatılan efsaneler, her ne kadar savaş efsaneleri gibi görünse de burada dikkat çekilmek istenen nokta velilerin kerametleri olduğu için, savaş efsaneleri olmaktan çok dinî efsanelerdir. Âlemin nizamının abdallar, meczuplar, erenler, veliler ile sağlandığını ve onların her zaman halkın içinde olup da kendilerini gizlediklerini belirten Oruç Bey, dinî efsaneler aktarmaktadır. Bunlar, gören ya da işitenler tarafından anlatılmıştır. İlkine göre erenler askerlere yardım etmişlerdir: "Ve dahı ba'zi râvîler eydür: Haber alup görenlerden ve işidenlerden didiler kim, gayberenleri gelüp gâzîlere yardım itdüklerin" (2008: 158). Hatta birinin anlatımına göre, daha savaş başlamadan onlar savaş yerine ulaştıklarında iki yüz ila iki yüz elli ölü ve yaralı kâfirin üst üste yığıldıklarını görmüşlerdir. Bunların kim tarafindan bu hâle getirildiğini anlayamayıp, Allah tarafindan kendilerine yardım edildiğini düşünmüşlerdir: "Ve bir râvî dahı rivâyet itdi kim: Biz dahı cenk yüzine varmadın gördük kim, bir yirde yüz elli iki yüz mikdârı var, kâfir uluları kırılmış yatur, kimi diri ve kimisi öli, birbiri üzerine yıgılmış yaturlar. Bilmedük kim, bunları kimler kırmışlardur. Kudret'den kırılmış bigi” (2008: 158). Başka bir anlatımda ise, gazilerin önünden giden küçük bir top mermisi kâfir askerlerini dağıtmıs ve bunu gören gaziler Allah'a sığınıp kâfirlerin üzerine yürümüş ve onları kılıçtan geçirmişlerdir.

Ve bir râvî dahı didi kim: Bir dâne-i kicük gâzîlerün önince kâfirler leşkerine bile girüp bile çıkdı. Gâzîler dahı bu alâmeti zâhiren ve bâtınen gözleriyile görüp, göyüllerine ilhâm-1 Rabbânî olup Hak taâlâya sıg1nup, bir azîm cenk itdiler kim, kâfirlerün topına, tüfeğine, zenberegine bakmayup evvel atlusına kılıç koydılar. (2008: 158)

Savaşlarla ilgili olarak anlatılan başka bir efsaneye göre, savaş meydanında iken gökyüzünde beyaz kuşlar, askerleri korumak için üzerlerine sayvan olurlar ve kâfirlerin üzerine hücum edip onlar üzerinden gelen siyah kuşları dağıtırlar. Burada akla Fil Suresi gelmektedir. Habeşistanlı Komutan Ebrehe'nin Mekke'ye saldırmasını ve ordusu ile yok olup gitmesini konu alan surenin 3. ayetinde "Onların üstüne sürü sürü kuşlar gönderdi” denmektedir (Kur'ân-ı Kerîm Açılamalı Meâli 2002: 624). Efsane Oruç Bey'de şu şekilde geçer: "Ve bir râvî dahı rivâyet itdi kim: Havâ yüzinde ak kuşlar gelüp gâzîlerün üzerine sayvân olup turup, kâfirler üzerine hücum idüp, kâfirler üzerinden gelen kara kuşları varup tagitdılar" (2008: 158). Bu efsanede heterodoks İslam’ı Sünni 
ve Şii İslam'dan ayıran bir inanç olan "don değiştirme" (metamorfoz) karşımıza çıkmaktadır. Metamorfoz, heterodoks menkıbelerde karşımıza çıkan İslam öncesi Uzak Doğu ve İran dinleri kaynaklı inanç motiflerinden biridir (Ocak 2005: 206). Ancak, evrensel bir nitelik taşıyan metamorfozun kökü mitolojiye dayanmaktadır. Nitekim, Yunan mitolojisinde Athena tarafindan örümceğe dönüştürülen Arakne (Can 1997: 50), Apollon tarafindan defne ağacına dönüştürülen Daphne (Can 1997: 57), öldükten sonra Apollon sayesinde sümbül olan Hyakinthos (Can 1997: 58) ve Artemis'in hiddetiyle geyiğe dönüşen Akteon (Can 1997: 68) bu motifin eskiliği ve evrenselliğinin güzel örnekleridir.

İslamiyet'i kabul eden Türklerde Şamanizmin en önemli izleri, heterodoks dervişlerin istedikleri zaman bir hayvan veya kuş şekline girebilmeleridir. Şaman giysisinde kuş simgesi önemli bir yere sahiptir. Giysilerde yer alan kuş tüyleri, hatta kuş şeklindeki şaman giysisi, şamana kuş şeklinde yeni ve sihirli bir beden verme işlevi görür (Eliade 1999: 186). Heterodoks dervişlerin menkıbelerindeki metamorfoz olayında dört kuş türü karşımıza çıkmaktadır. Bunlar; doğan, güvercin, şahin ve turnadır. Dervişlerin metamorfozlarında bu kuşların yer alması, İslamiyet sonrası dönemde, eski inançların etkisinin devam ettiğini göstermesi bakımından önemlidir. Nitekim Altay mitolojilerinde ve türeme tasarımlarında doğan ve şahin, kendisinden gelindiğine inanılan hayvan-ata, hayvan-ana (Korkmaz 2003: 57,137), güvercin, uzun yaşamın simgesi olduğuna inanılan kutsal kuş (Korkmaz 2003: 75), turna ise zenginliği, serveti, refahı ya da uzun yaşamı, ölümsüzlüğü simgeleyen kuştur (Korkmaz 2003: 151).

Efsanede, bu kuşların, kuş donuna girmiş derviş oldukları belirtilmemiş olmakla birlikte, bunların bir savaş sırasında askerlere yardım etmek gibi bir amaçla gelmiş kuşlar olduğu göz önüne alınırsa, Allah tarafından yardıma gönderilen kuş donlu dervişler olduğu düşünülebilir. Hacı Bektaş Veli'nin menkıbelerinden birine göre Hoca Ahmed Yesevi'nin nefes oğlu Kudbeddin Hayder'in, kâfir olan Bedahşan ülkesi ile yapılan bir savaşta esir edilmesi üzerine Hacı Bektaş Veli, Türkistan'a gelir ve Ahmed Yesevi ile konuşur. Bedahşan halkının Horasan halkına yaptığı eziyetleri duyunca derhal silkinerek şahin şekline girer ve Bedahşan'a gider. Uça uça Kudbeddin Hayder'in hapsedildiği mağaraya gelir. Burada tekrar silkinerek insan şekline girer ve Kudbeddin Hayder'i kurtararak Ahmed Yesevi'nin dergâhına getirir (Manâkıb-ı Hünkâr 1995: 10-11). Daha sonra savaşarak Bedahşan'ı zapteden Hacı Bektaş Veli'ye beyler, padişahlık teklif ederler. Ama o, bunu kabul etmez ve silkinip güvercin şekline girerek Hoca Ahmed Yesevi'nin yanına gelir (1995: 13). Görüldüğü üzere Hacı Bektaş Veli, zalimlere karşı şahin; erenlere, mazlumlara karşı ise güvercin şekline girmektedir.

Bu efsanedeki düşman askerlerin üzerinden gelen siyah kuşların, onlara yardım eden din büyükleri olduğunu söylemek güç olmakla birlikte, bu siyah kuşların, 
halkın heterodoks muhayyilesinde kuş donuna girmiş dervişlere rakip olarak ortaya atılmış bir sembol olduğu düşünülebilir. Burada siyah ve beyaz sembollerine gönderme yapılmıştır. Zira hemen hemen bütün mitolojilerde ve inanç sistemlerinde beyaz, saflı̆g1 ve temizliği; siyah ise kötülüğü temsil etmektedir.

Oruç Bey, Kostantin'de denize hırkasını serip oturmak suretiyle karşı tarafa geçen bir veliden bahsetmektedir. "Irmak veya deniz üzerinde yürümek", heterodoks menkıbelerde karşımıza çıkan ama metamorfozdan farklı olarak Kitab-1 Mukaddes kaynaklı inanç motiflerinden biri olup Hz. İsa'nın denizi yürüyerek geçmesine dayanmaktadır (Ocak 2005: 277). Motifin aslı her ne kadar deniz üzerinde yürümek şeklindeyse de, efsanede denizi oturarak geçmek şekli ile karşımıza çıkmaktadır. Hacı Bektaş Veli, Ulu Abdal ve Kiçi Abdal adlı iki dervişle birlikte Rum ülkesine göndereceği Sarı Saltuk’a bir seccade verir. Karadeniz kıyısındaki Harmankaya'ya gelen bu üç derviş, aynı seccadenin üzerine otururlar. Sarı Saltuk, seccadeye erenler nereye götürürse oraya gitmesini söyler ve seccade Gürcistan’a gider. Bu durumu gören Gürcistan kralı Görliş ve beyleri, dervişlerin Allah'ın sevgili kullarından olduğunu düşünüp, Sarı Saltuk'un imana davet etmesi üzerine Müslüman olurlar (Manâkıb-ı Hünkâr 1995: 45).

Türklerin İslamiyet'i kabulünden itibaren gerek halk inançları arasında gerekse edebiyatta önemli bir yere sahip olan Hızır kültü, yüzyıllardır halk arasında bilinen ve anlatılan destanlar, efsaneler, halk hikâyeleri, masallar ve menkıbeler içinde yer alan önemli bir dinî külttür. Bu kültün kaynağı Kur'an-1 Kerim'deki Hz. Musa ve Hızır kıssasıdır. Ancak Kur'an-1 Kerim'in indirilişinden çok uzun zaman önce eski Doğu efsanelerinde Hızır görülmektedir. Şarkiyatçı Arent Jan Wensinck, Encyclopédie de l'Islam'a yazdığı "al-Khadir" maddesinde Hızır inancı üzerinde durmuş ve kıssanın kaynaklarının Gı1gamış Destanı, İskender Efsanesi ve Yahudi Efsanesi olduğunu belirtmiştir (aktaran Ocak 2007: 52).

Halk inançlarında Hz. Hızır genellikle insanların karşısına derviş, aksakallı bir ihtiyar ya da dilenci şeklinde çıkmaktadır. Onun işlevi ise zor durumlarda, felaketlerde ve savaşlarda yardım etmek, iyileri ödüllendirip kötüleri cezalandırmak ve insanları bolluk ve berekete kavuşturmaktır (Ocak 2007: 109-118). Oruç Bey'in aktardığı bir olayda Hz. Hızır, boz atlı, yıldırım kamç1l, yeşil donlu bir derviş şeklinde karşımıza çıkmakta ve kendisini "Allah tarafından zorda kalmış insanlara yardım için görevlendirilmiş Hızır Peygamber" olarak tanıtmaktadır. Burada boz atlı, yeşil elbiseli Hızır, yük taşımak için yola çıkmış olan bir arabacının öküzünün kırılan ayağını üç kez sıvazlar ve ayağı iyileştirir. Arabacı böylelikle yoluna devam eder. Efsanenin devam eden kısmında Hızır, kendisine Allah tarafından verilen bir görevden bahsetmektedir. Arabacı, Hızır'ı fark etmeden önce önden iki kara elbiseli ve 
kara atlı kişinin gittiğini görür. Bunların kim olduğunu sorduğunda, Hızır onların Allah tarafından orada yaşayan halkın arasına taun hastalı̆̆ını yaymak için gönderilmiş öletler olduğu cevabını verir. Ancak daha sonra taunun o şehirden çıkması istenmiş ve Hızır'a bu atlıların öldürülmesi görevi verilmiştir. Arabacının gördüğü bu iki atlı, Hızır'ın öldürmek için peşinden gittiği atlılardır. Hızır eğer onları denize girmeden yakalayıp öldürebilirse, o şehirde otuz yıl taun hastalığının görülmeyeceğini belirtmiştir:

Ve girü bu yıl içinde vilâyetimüzde bir kıssa dahı zâhir oldı. Sahîh gören râvî ağzından haber alınup yazıldı, Rebiüulevvel ayınuy yigirmi üçünci gicesinde Çehârşenbih gicesinde vâkı' oldı. Meger birkaç arabacılar Gelibolı'dan yük dutup gelüp Edrene'ye gitmekde. Yolda gelüp Bolayır'un görinür yerinde bir kaldırım varmış. $\mathrm{Ol}$ arabacılar ol kaldırım üzerinde gelürken nâgâh bir arabacınuy bir su sıgırı öküzünün bir ayagı bir delüge geçer. Bir ayagınun dizi gözinden sınur. Arabacılar gördiler kim, hâl böyle oldı. Yoldaşları öküzlerini, arabacıyı anda koyup gitdiler. Varup Bolayır'dan öküz getüreler ve araba getüreler. Hem ol su sıgırı öküzi arabaya urup alup Bolayır'da bogazlayup satalar. Yoldaşları arabacılar gitdiler Bolayır'a. Öküz issi arabası katında nahs tâli'ine aglayu. Yaluyuz ol arada tururken nâgâh yatsu vaktinde bir küpürdü belürür, atlular belürür. Arabacı ol at tapırdusını işidüp kaçup araba altına girür. Meger iki kara tonlu, kara atlu kimseler gelüp yıldırım gibi geçüp gitdiler. Anlaruy akabınca girü bir boz atlu, yeşil tonlu, yıldırım kamçılu kimesne gelüp çağırdı, âvâz virdi kim: Bre arabacı! diyü. Arabacı dahı korkusından cevâb virüp didi kim: ne buyurursız? diyü. O1 boz atlu, yıldırım kamçılu, yeşil tonlu didi kim: Hîç bu tarafa iki akar atlu, kara tonlu kimesneler geçdi mi? diyü. Arabacı cevâb virdi kim: Belî geldiler geçdiler, diyü.

Ve girü ol boz atlu, yeşil tonlu didi kim: İy arabacı! Sen yalunuz bunda neylersin? Yoldaşlarun kanı kanda gitdi? didi. Arabacı dahı didi kim: 'Sultânum! Benüm bir öküzümün bir ayagı sindı bir delüge geçdi. Yoldaşlarum şehirden öküz, araba getürmege gitdiler' didi. Arabacı dahı ayagı sınan öküzi gösterdi. Ol boz atlu, yeşil tonlu boz atdan inüp gelüp ol öküzüy sınan ayagını üç kerre sığadı. Dahı ol öküzi kaldurdı. Öküzün ayag1 sağalmış. Arabacıya didi kim: 'Gel öküzüni koş yoluna git' didi. Geldi kim atına bine. Arabacı dahı ana varup dahı ünlendi. Didi kim: Sultanum! Sizlere kim dirler? Ol boz atlu, yeşil tonlu didi kim: Ben Hızır Peygâmberem. Kalmışlara meded irici. Hak tebâreke ve taâlâ hazretlerinün yed-i kudreti birle ben za'if kulını bu yolda bu hususa komışdur, didi.

Ve girü arabacı didi kim: Sultânum! O1 öydin giden kara atlu, kara tonlular kimlerdür? didi. Hizır Peygâmber aleyhi's-selâm didi kim: 'O1 atlular öletdür, anlar tấ ûnlardur. Bu halkuy içinden çlkmazlar' didi. Anlar dahı Hak taâlâ emriyiledür. Hak emrinden taşra çıkmazlar ve illâ kudret şimdi şöyle yüz gösterdi kim, bu halkun içinden tâuûn götürile. 
İmdi girü Hakk'un emriyile ben kulını bunlara havâle itdürdi. Bunlar sekiz kişiydi, altısını katl itdüm ikisi kaldı. Eger bu ikisini denize girmedin katl idersem otuz yl bu halk içinde tấ ûn olmaya götürile didi. Atına bindi ve gitdi, gayb old. (2008: 163-164)

Bu çalı̧̧mada ele alınacak son efsane, eserin "Kostantiniyye ve Ayasofya Efsaneleri” adlı bölümünde yer alır. Daha geniş bir anlatımına Evliya Çelebi $S e-$ yahatnamésinde de rastlanmaktadır. Bu efsanede Hz. Muhammed'in doğumu ile yıkılan Ayasofya'nın kubbesi, onun ağzının suyu ile inşa edilmektedir. Stefanos Yerasimos'un Türk Metinlerinde Konstantiniye ve Ayasofya Efsaneleri adlı eserinde ele alınan metin Friedrich Giese tarafindan yayımlanan anonim bir Osmanlı kroniğine dayanmaktadır. Bu metinde adı geçen efsaneye yer verilmediği için burada ele alınması uygun olacaktır. $\mathrm{Bu}$ anonim metinde, Harkıl'’n çeşitli armağanlar ile Hz. Muhammed'e elçi gönderip ondan icazet aldığ belirtilmektedir (2012: 48-49). Yerasimos, daha ileri tarihteki metinlerde bu icazetin Hz. Muhammed'in içine tükürdüğü bir miktar toprakla birlikte gönderilmesi ve kubbenin bu şekilde sağlamlaştırılması nedeniyle, Müslümanların ileride Ayasofyàya sahip çıkma hazırlığı yaptığı sonucunu çıkarmaktadır. Böylece Ayasofya'nın kendilerinden Müslümanlara geçmesi sürecinde imparatorun aracı vazifesi gördüğü belirtilmektedir (2012: 233).

Harkıl'ın Kostantiniyye'de hüküm sürdüğü sırada, zamanın rahipleri huzuruna gelirler. Arap diyarına Muhammed adlı peygamberin gelmesiyle kubbenin yıkıldığını ve yeniden inşa edilmesi için de ondan yardım istenmesi gerektiğini söylerler. Bunun üzerine Harkıl çeşitli hediyeler ile Hz. Muhammed'e elçi gönderir. Hz. Muhammed, bir taşa ağzının suyundan sürer ve bunu elçiye verir. Bu taş, kubbe inşa edilirken malzemenin arasına koyulur ve yapımı tamamlanan kubbe bir daha yıkılmaz.
Âkıbet ol zamânuy râhibleri ittifâk idüp Harkıl'a didiler kim: 'Diyâr-1 Arab'da bir peygâmber zâhir olmışdur Muhammed adlu. Bu kubbe anuy gelmesiyle yıkılmı̧̧dur. Girü dermân andan olur' didiler. Pes Harkıl Kayser agır armaganlar ile Hazret-i Risâlet'e salla’llâhu aleyhi ve sellem elçi gönderdi, hâli i'lâm eyledi. Ol vakt Hazret-i Habîbu'llâh aleyhi's-salâtü ve's-selâm peygamberlik gelmişdi. Bir [ri]vâyetde gel- memişdi. Hazret-i Risâlet aleyhi's-selâm dahı agız yarından alup bir küçücük taşa sürdi. Dahı ol taşı alup gelen elçiye virdi. Elçi ol taşı alup gelüp ol büyük kubbenün arasına bile yapdılar. Kubbe andan soyra tu- rup yıkılmadı. Tamâm oldı. Şimdiki zamânda dahı yeri âşikâre göri- nür. Sogradan yapıldugi ma'lûmdur. (2008: 105)

Evliya Çelebi, bu efsaneyi daha geniş olarak Seyahatname'de aktarmaktadır. Ancak bu iki efsane arasında farklılıklar görülmektedir. Evliya Çelebi'nin aktardığ1 efsaneye göre, Hz. Muhammed doğduğu gece Ayasofya’nın kubbesi yıkılır. Hz. Hızır Ayasofya'daki rahiplere yaşlı bir şeyh suretinde görünür ve 
"Eğer bu camiin kubbesini tamir edelim derseniz, şimdi zuhur eden âhir zaman Muhammed'ine varın, ağzı suyundan su alıp zemzem suyu ile karıştırıp burada kirece ağZı suyunu karıştırın, sonra kubbeyi tamir edin. Yoksa başka çare yoktur" der ve kaybolur. Rahipler bu yaşlı şeyhin Hz. Hızır olduğunu anlarlar ve üç yüz patrik ve rahip yola çıkar. Mekke'de Hz. Muhammed'i bulan rahipler, "Ey Muhammed, sen dünyaya geldiğin gece bizim Kostantiniyye'de Ayasofya adlı bir kilisemizin kubbesi yıkıldı. Birkaç kez yaptık, temel tutmadı. Mübarek ağzın suyundan bu mücevher hokka içine biraz koy, kirece karıştırıp ibadethanemizi tamir edelim, ola ki yerinde dura" derler ve Hz. Muhammed de bu ricayı kabul eder. Sonra rahipler bu hokkanın içine zemzem suyu doldurup, yetmiş deve yükü Mekke toprağı ve yetmiş deve yükü zemzem suyu ile yola çıkarlar. Kostantiniyye'ye vardıklarında kireci bu ağız suyu, zemzem ve Mekke toprağı ile karıştırıp kubbeyi tamir ederler. (2006: 55-56)

\section{Sonuç}

Klasik dönem Osmanlı tarihçilerinden olan Oruç Bey'in Tevârihb-i Âl-i Osman adlı eserinde, önemli bir sözlü kültür ürünü olan efsanelere rastlanmaktadır. Eserde, yer adı verme ile Kostantiniyye ve Ayasofya'yla ilgili olanlar dışındaki efsaneler, tarihî ve dinî efsanelerdir. Tarihî efsaneler, felaketlerle ve fetihlerle ilgili olarak anlatılmaktadır. Tespit edilen efsanelerin, bu sözlü kültür ürününün temel özelliklerinden olan inanış ve olağanüstülük barındırma vasfinı taşıdıkları görülmektedir.

Eserdeki dinî efsanelere bakıldığı zaman savaşlarda evliyanın askerlere yardıma geldiği görülmektedir. Bu efsanelerin kayda geçirildiği 15. yüzyıldan günümüze gelindiğinde, halkın gözünde savaşın, dolayısıyla da tarih algıs1nın pek değişmediği görülmektedir. Nitekim Çanakkale Savaşları hakkında anlatılan, evliyanın askere yardıma gelmesi ve onların sayesinde savaşın kazanılmasına dair Anadolu sözlü kültüründe yer alan efsaneler, Oruç Bey'in dönemindeki tarih alg1sı ile günümüz tarih algısı arasındaki benzerliği göstermektedir.

Eserin bir Osmanlı tarihi olduğu göz önüne alındığında, eserde yer alan efsanelerin tarihî ve dinî efsaneler olması son derece doğaldır. Sonuç olarak, II.Bayezid devri tarihçilerinden Oruç Bey'in Tevôrihb-i Âl-i Osman adlı eserinin Osmanlı tarihi ve dil araştırmaları için olduğu kadar, 15. yüzyıl Türk sözlü kültür geleneği için de zengin bilgiler içeren önemli bir kaynak olduğu söylenebilir. 


\section{Kaynaklar}

Alpaslan, İsmet (1991). "Kıbrıs Çıkartmasındaki Ahmed-i Hani”, Milli Folklor 12, s.46. Alptekin, Ali Berat (1980). "Silifke'de Kırtıl Dağı'nın Efsanesi”, Türk Folkloru 11, s.6-7. Boratav, Pertev Naili (2000). 100 Soruda Türk Halk Edebiyatı, İstanbul: Gerçek Yayınevi. Can, Şefik (1997). Klasik Yunan Mitolojisi, İstanbul: İnkılap Yayınları.

Elçin, Şükrü (2001). Halk Edebiyatına Giriş, Ankara: Akçă̆ Yayınları.

Eliade, Mircea (1999). Şamanizm, Çev. İsmet Birkan, Ankara: İmge Kitabevi.

Erhat, Azra (2003). Mitoloji Sözlüğü, İstanbul: Remzi Kitabevi.

Dülger, Elif (2012). “Oruç Bey'in Tevârih-i Âl-i Osmân Adlı Eserine Göre Türklerde Yer Ad1 Verme Geleneği”, Turkish Studies 7/3, s.1067-1074.

Evliya Çelebi (2006). Evliya Çelebi Seyahatnamesi (Topkapı Sarayı Bağdat 304 Yazmasının Transkripsiyonu-Dizini), Haz. Orhan Şaik Gökyay, 1. cilt, İstanbul: Yapı Kredi Yayınları.

Karadavut, Zekeriya (1992). "Yozgat Efsaneleri (İnceleme-Metin)”, yayımlanmamış yüksek lisans tezi, Konya.

(2011). "İstanbul'un Fethiyle İlgili Bir Efsane: Didon Hilesi ve Yayılma Alanları", 7. Uluslararası Türk Kültürü Kongresi Bildiriler I (İstanbul Taribi: Medeniyetlerin Buluşma Noktası Olarak İstanbul), Ankara: Atatürk Kültür Merkezi Yayınları, s.647-658.

Kaya, Doğan (2001). Folklorumuzda Beddua Söyleme Geleneği ve Türk Halk Şiirinde Beddualar, Ankara: Atatürk Kültür Merkezi Yayınları.

Korkmaz, Esat (2003). Eski Türk Inançları ve Şamanizm Terimleri Sözlüğ̈̈, İstanbul: Anahtar Kitaplar Yayınevi.

Kur'ân-ı Kerîm Açılamalı Meâli (2002). Haz. Hayrettin Karaman, Ali Özek, İbrahim Kâfi Dönmez, Mustafa Çağrıc1, Sadrettin Gümüş, Ali Turgut, Ankara: Türkiye Diyanet Vakfi Yayınları.

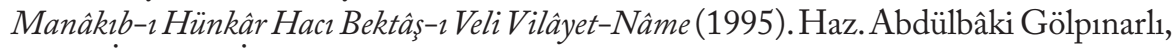
İstanbul: İnkilap Kitabevi.

Ocak, Ahmet Yaşar (1997). Kültür Taribi Kaynağı Olarak Menâkıbnâmeler: Metodolojik Bir Yaklaşım, Ankara: Türk Tarih Kurumu Yayınları.

— (2005). Alevî ve Bektaşî̀ İnançlarının İslâm Öncesi Temelleri, İstanbul: İletişim Yayınları.

(2007). İslam-Türk Inançlarında Hızır-İlyas Kültü, İstanbul: Kabalcı Yayınevi.

Oruç Beğ Taribi (2008). Haz. Necdet Öztürk, İstanbul: Çamlıca Basın Yayın.

Öztürk, Necdet (2011). Saray Penceresinden 14.-15. Yüzyıl Osmanl Sosyal Hayatı, İstanbul: Yitik Hazine Yayınlar1.

Sakaoğlu, Saim (2009). Efsane Araştırmaları, Konya: Kömen Yayınları.

Seyidoğlu, Bilge (1986). "Gezgin Efsaneler Üzerinde Bir Araştırma: Norveç ve Türkiye (Erzurum) Efsaneleri”, III. Milletlerarası Türk Folklor Kongresi Bildirileri (2. Cilt - Halk Edebiyatı), Ankara: Kültür ve Turizm Bakanlığ1 Yayınları, s.359-363.

Wensinck, Arent Jan (1993), “al-Khadir”, Encylopédie de l’Islam, Leiden: E. J. Brill.

Yerasimos, Stefanos (2012). Türk Metinlerinde Konstantiniye ve Ayasofya Efsaneleri, İstanbul: İletişim Yayınları.

Zebîdî (1986). Sabibi Bubari Mubtasarı Tecrîdi Sarîh Tercemesi ve Şerbi, 4.-5. cilt, Haz. Kâmil Miras, Ankara: Diyanet İşleri Başkanlığı Yayınları. 


\section{ABSTRACT \\ Legends Told by Oruç Bey and Their Place in Turkish Legends}

Legends are oral culture products that exist for centuries, and their classification includes "historical legends" which is an evidence showing the relationship between historical sources and legends. In almost every historical source, legends of war and conquests are encountered. The purpose of this study is to determine legends which were told by Oruç Bey, a historian of Ottoman Empire in the 15th century, in his work entitled Tevârih-i Âl-i Osman. Oruç Bey has not only confined himself to writing a history book, but also has wrote down proverbs, idioms, curses, legends, folk beliefs, traditions, customs, and many other cultural information like stories of naming a place as well. That work is an important source for those who want to investigate the first two centuries' history of the Ottoman Empire as well as Turkish culture of the era.

Keywords: Turkish legends, historical legend, religious legend, Oruç Bey, Tevârih-i Âl-i Osman 
